\title{
意識障害
}

\author{
卜部 貴夫
}

Key words : 意識障害, 意識レベル, 評価スケール, 局所神経徴候, 初期対応, AIUEOTIPS

〔日内会誌 99:1082～1089，2010]

はじめに

意識障害は，救急診療において遭遇すること の多い症候である，意識障害には，意識の消失 が一過性の場合と遷延する場合とがある。一過 性意識障害は脳組織の可逆的な機能障害を来し た状態であり，広義には失神やてんかん発作も 含まれる。一方, 遷延性意識障害は脳機能障害 が持続した状態であり, 何らかの器質的疾病に 起因することが多い. 遷延性意識障害の原因は, 頭蓋内疾患から全身性疾患まで多岐にわたり， 生命に関わる危険な疾病を有する可能性が高く, 早期の診断と治療が予後に大きな影響を及ぼす.

本稿では内科救急における，意識障害患者に 対する専門医への引継ぎまでの初期評価および 対応（初期治療）について解説する.

\section{1. 意識障害の概念と病態}

「意識」には，覚醒(awakeまたはarousal)と， 認識 (awareness) といった 2 つの要素がある. 前者は覚醒度として意識水準をさし, 後者は自 己や周囲の認識といった意識の内容を意味する. 通常, 意識障害は覚醒度の障害をさすことが多 いが, 意識内容の変化を伴う場合もある，意識 障害は様々な原因により意識水準の調節機構が

うらべ たかお：順天堂大学脳神経内科
障害されることで発症する。意識水準は，上行 性網様体賦活系 (ascending reticular activating system：ARAS）という脳幹からの大脳皮質全 体への上行性投射により調節されている。 その ため意識障害は, ARASの障害もしくは両側大脳 皮質の広範な障害により出現する1,2).

\section{1）覚醒度の障害の分類}

意識障害は覚醒度により傾眠 (somnolence), 昏迷 (stupor), 半昏睡 (semicoma), 昏睡 (coma), 深昏睡 (deep coma) に分類される. しかし, 定 義が曖昧な部分も多いため救急患者の意識レべ ルの診断には最近ではほとんど用いられず, 次 に述べる評価スケールにより評価される.

2）意識障害の評価スケール

意識レベルの客観的評価には, Japan Coma Scale (JCS) (表 1) やGlasgow Coma Scale (GCS) (表 2) が用いられるが, 最近GCSとJCSの長所を 取り入れ改良されたECS (Emergency Coma Scale）が開発された（表 3).

\section{2. 意識障害患者への初期対応と診療の進 め方（初期対応のアルゴリズム)（図）}

\section{1）患者搬送後 10 分以内の初期対応}

意識障害を伴う救急患者の初期対応は, 迅速 かつ的確に行う必要がある。そのためにも初期 $\mathrm{ABCD}$ 評価 (primary $\mathrm{ABCD}$ ) と 2 次 $\mathrm{ABCD}$ 評価 (secondary $\mathrm{ABCD}$ ) は, 患者搬送後 10 分以内に 行うことが必須である3,4. 
表 1. Japan Coma Scale (JCS)

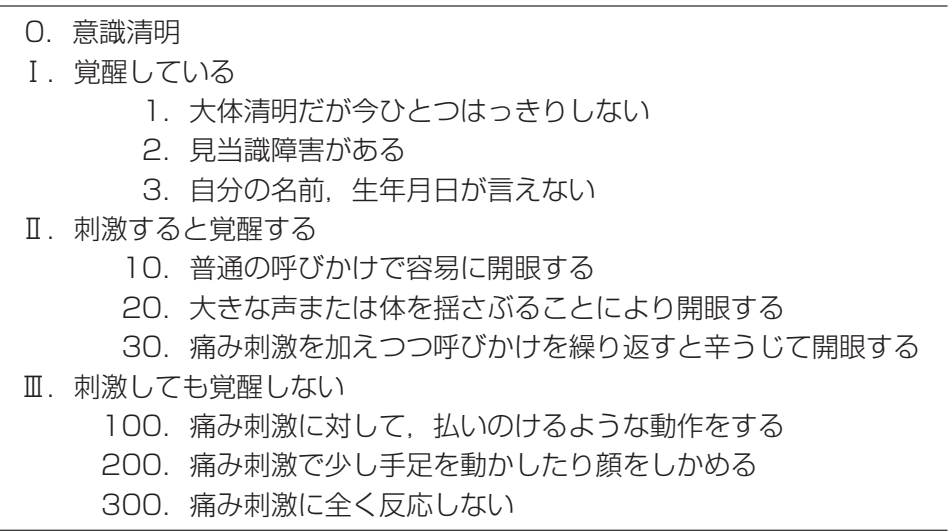

(注) R:Restlessness (不穏), I:Incontinence (尿失禁)，A：Apallic state（失外套状態）or Akinetic mutism（無動無限）

\section{表 2. Glasgow Coma Scale (GCS)}

\begin{tabular}{c|c}
\hline 1. 開眼 (eye opening, E) & $E$ \\
\hline 自発的に開眼 & 4 \\
呼びかけにより開眼 & 3 \\
痛み刺激により開眼 & 2 \\
なし & 1 \\
\hline 2. 最良言語反応 (best verbal response, V) & $V$ \\
\hline 見当識あり & 5 \\
混乱たた会話 & 4 \\
不適当な語 & 3 \\
理解不明の音声 & 2 \\
なし & 1 \\
\hline 3. 最良運動反応 (best motor response, M) & $\mathrm{M}$ \\
\hline 命令に応じて可 & 6 \\
疼痛部へ & 5 \\
逃避反応として & 4 \\
異常な屈曲運動 & 3 \\
伸展反応（徐脳姿勢) & 2 \\
なし & 1 \\
\hline
\end{tabular}

初期 $\mathrm{ABCD}$ 評価と対応はA（airway：気道確 保), B (breathing: 呼吸の評価, 人工呼吸), C (circulation：循環の評価 (脈の確認), 胸骨圧 迫, CPR：cardio-pulmonary resuscitation)を系 統的に行う。その際に傷病者への簡単な呼びか けに対する反応をみて, 意識障害の有無を確認 し, 視診, 触診, 脈診に基づき重症度を判断す る. 脈が触知されない場合には，心電図モニタ
付き除細動器または自動体外式除細動器 (AED) を装着し，D(defibrillation：除細動，主にAED） を実施する。

引き続き 2 次 $\mathrm{ABCD}$ としてA (airway：気道の 評価, 確実な気道確保), B (breathing：呼吸状 態の観察, 換気, 酸素投与, 酸素飽和度), C (circulation：循環動態の観察，心電図モニタと 診断, 静脈路確保, 適切な投薬), D (differential diagnosis：鑑別診断，考える）を系統的に実施 する.

\section{2）意識障害患者の診療の進め方}

\section{(1) 問診（病歴聴取）}

意識障害患者では，本人からは正確な病歴の 聴取が不可能な場合が多いので，家族や同伴者 から以下のポイントに留意して問診を行う.

(1)発症時期, 発症様式

日中活動時か, 安静時か, 起床時かといった 発症状況と，発症の時刻が明確であるかを確認 する. 発症時刻が特定できない場合は正常状態 の最終時刻を確認する。症状出現が突発性か, 進行性かを確認する.

(2)持続時間

症状は持続性か, 反復性か, あるいは一過性 であったかを聞く。 
表 3. Emergency Coma Scale (ECS)

I 、覚醒している（自発的な開眼・発語または合目的な動作をみる）

1. 見当識あり

2. 見当識なしまたは発語なし

I．覚醒できる（刺激による開眼・発語または従命をみる）

10. 呼びかけにより

20. 痛み刺激により

III. 覚醒しない（痛み刺激でも開眼·発語および従命がなく運動反射のみをみる）

100L．痛みの部位に四肢を持っていく，払いのける

100W. 引っ込める（脇を開けて）または顔をしかめる

200F. 屈曲する

200E. 伸展する

300. 動きが全くない

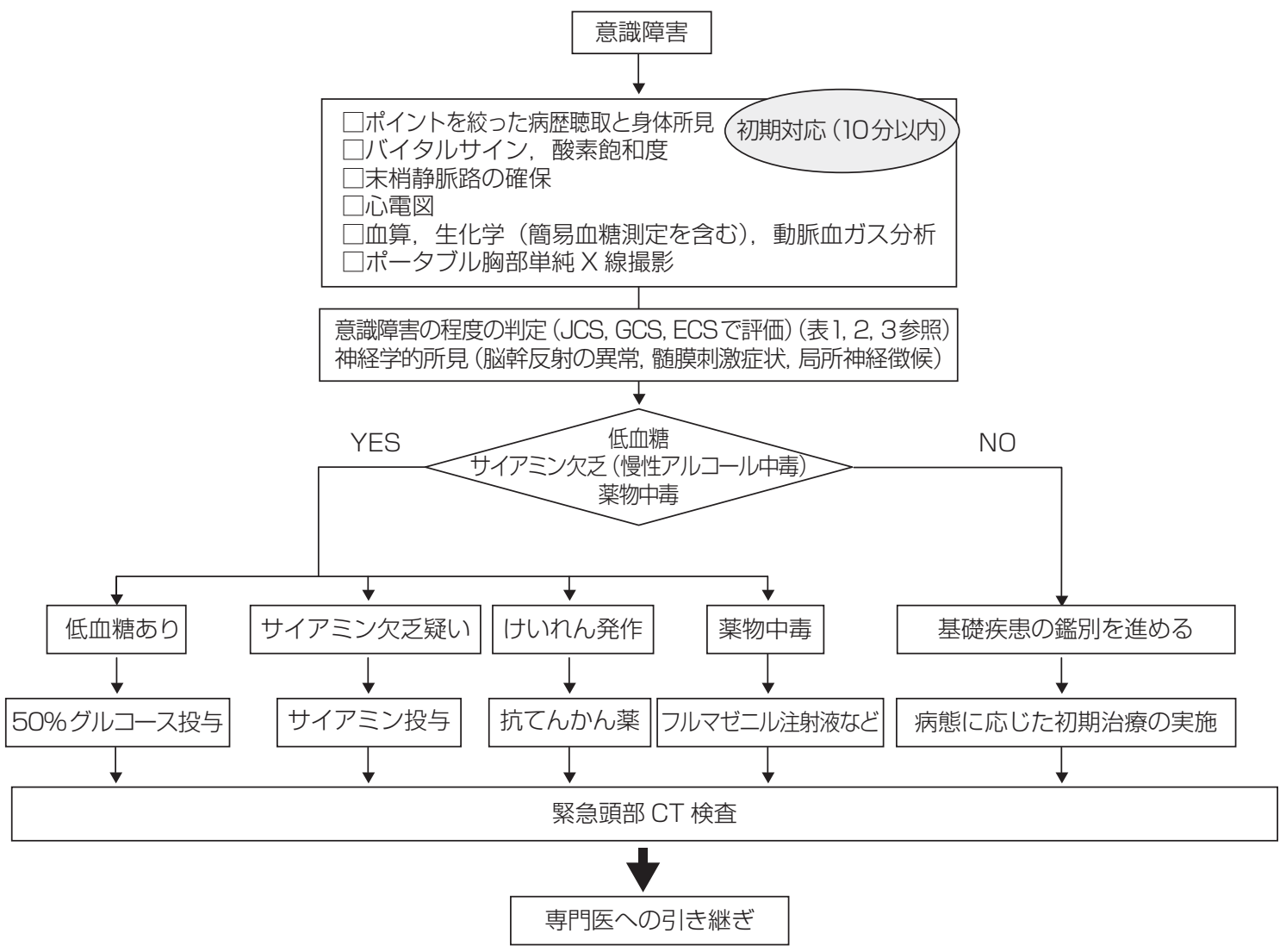

図 . 初期対応のアルゴリズム

(3)随伴症状

意識障害と同時に発熱, けいれん, 頭痛, 運 動麻痺などの局所神経症状, 悪心, 嘔吐, 呼吸 困難などを伴っているかを聞く
(4) 既往歴

高血圧, 脂質異常症, 糖尿病, 脳卒中, 心疾 患などの既往歴, 現在治療中の疾病, 服用中の 薬剤, 飲酒歴を聴取する. 家庭や職場での精神 
状態を確認する.

(2) 身体所見

(1)視診

患者の表情や姿勢から重症か否かを判断する. 貧血, チアノーゼ, 栄養状態, 外傷の有無を確 認する.

\section{(2)触診}

四肢冷汗, 肝脾腫, 浮腫を確認する。

(3)聴診

心音, 呼吸音, 腸グル音を聴取し, 頸動脈や 四肢血管での血管雑音の有無を確認する.

(4)打診

心拡大, 肝脾腫を診察し, 心疾患や肝疾患な どの基礎疾患の存在を確認する.

(5)血圧

血圧を測定し，急激な血圧上昇や血圧低下を 確認することは, 循環不全状態の評価に必要で ある．頭蓋内圧が充進すると血圧が上昇するの で，速やかに血圧測定を行う。

(6)呼吸状態 $1,2,5)$

呼吸状態から脳障害の部位を診断することが できる. Cheyne-Stokes呼吸は, 両側大脳半球, 間脳, 橋上部の障害, 中枢性神経原性過換気は 中脳下部から橋上部の被蓋の障害, 無呼吸性呼 吸は橋中部から下部の背外側被蓋の障害, 群発 呼吸は橋下部から延髄上部の被蓋の障害, 失調 性呼吸は延髄背内側網様体の障害でみられる。

(7)神経学的所見 $1,2,5)$

意識レベル，瞳孔の左右差と対光反射, 眼球 運動, 脳幹反射, 肢位, 運動麻痺, 深部腱反射 と病的反射, 髄膜刺激症状などの神経学的所見 から, 局所神経徵候の有無を確認する. 可能な 限り眼底を観察し, うっ血乳頭の有無から頭蓋 内圧立進を伴っているか否かを判断する。髄膜 炎やくも膜下出血では髄膜刺激症状を伴う場合 があり，注意深く診察を行う。

瞳孔の左右差と対光反射および眼球運動など の脳神経症状と脳幹反射の所見により脳障害の 部位を診断することができる.
A. 瞳孔

下記のような曈孔所見と障害の関連があるが, 緑内障をはじめとした眼疾患による修飾もみら れるため注意が必要である。

左右不同がみられる場合：

a）大きな瞳孔側の対光反射が消失, あるいは 緩慢 $\rightarrow$ 同側の動眼神経麻疩

b）両側の対光反射が保たれている 小さい曈 孔側のHorner症候群

左右同大の場合 :

a） pin point pupil (著しい縮瞳) $\rightarrow$ 橋被蓋部の 障害, モルヒネなどの薬物中毒

b）対光反射のある縮瞳 $\rightarrow$ 代謝性疾患, 小脳テ ントヘルニアによる間脳レベルの障害

c）中等度サイズの睹孔で対光反射なし $\rightarrow$ 中脳 レベルの障害

d）両側曈孔散大し対光反射消失 $\rightarrow$ 高度の脳幹 障害

B. 眼球運動

a）眼位の異常：共同偏視やskew deviation の有無を確認.

b）異常眼球運動：roving eye movementや眼 振の有無を確認.

- roving eye movement ; ゆっくり左右に動く 自動的な眼球運動. 大脳半球の障害などでみら れるが障害部位の特異性はなく, 脳幹機能が保 たれていることを示唆する.

c）前庭頭位反射：oculocephalic reflexを確認.

- oculocephalic reflex (人形の目現象) ; 患者 の頭を保持し右や左へ回旋させ, 回旋方向と反 対方向への眼球運動が誘発されれば陽性で, 脳 幹機能は保たれていることを示す.

(3) 検査

(1)採血.

糖代謝, 電解質, 肝機能, 腎機能に異常がな いか評価する.低血糖の鑑別は重要であるため, 必ず採血検体の一部を用い直ちに簡易血糖測定 を行う。 


\begin{tabular}{|c|c|c|}
\hline A & Alcoholism, Acidosis & 急性アルコール中毒，代謝性アシドーシス \\
\hline I & Insulin & インスリン (低血糖, 糖尿病性ケトアシドーシス) \\
\hline$U$ & Üremia & 尿毒症 \\
\hline E & Endocrine, Encephalopathy & 内分泌疾患, 肝性脳症 \\
\hline O & Ōxygen, Opiate & 低酸素血症，麻薬 \\
\hline $\mathrm{T}$ & Trauma, Temperature, Tumor & 外傷, 体温異常, 脳腫瘍 \\
\hline । & Infection & 感染症（髄膜炎·脳炎） \\
\hline$P$ & Psychiatric, Porphyria, Pharmacology & 精神疾患, ポルフィリア, 薬剤性 \\
\hline S & S̄yncope, Stroke, $\underline{\text { SAH, }}$ S-eizure, Shock & 失神, 脳卒中, クモ膜下出血, 痤攣, ショック \\
\hline
\end{tabular}

(2) 12 誘導心電図

心電図または心電図モニ夕を行い，不整脈や 虚血性心疾患の有無を確認する.

(3)胸部X線写真

心拡大, うっ血, 胸水の有無を確認する.

(4)動脈血ガス分析

酸素分圧, 二酸化炭素分圧, $\mathrm{pH}$, 重炭酸イオ ン濃度を計測する。低酸素血症や高炭酸ガス血 症,アシドーシスやアルカローシスを評価する.

(5)頭部単純CT (computed tomography)

くも膜下出血, 脳出血, 脳梗塞の他, 脳腫瘍, 脳膿瘍など器質的疾患の有無を確認する.

(6)脳脊髄液検査

頭蓋内圧艺進症状がなく, かつ, 頭部単純 CT で広範囲の占拠性病変が否定された状況で, 髄 膜炎や脳炎, くも膜下出血の確認が必要な場合 に実施する。

頭痛と発熱を伴う髄膜炎や, 脳動脈瘤のminor leakageが疑われる場合は脳脊髄液検査を行い, 髄液の細胞数増加, キサントクロミーからそれ ぞれが診断される。

\section{3. 鑑別疾患}

鑑別すべき主要疾患をAIUEOTIPS(アイウエ オチップス）として覚えておく（表 4). 検查に よって緊急処置を要する疾患, 準緊急処置を要 する疾患，その他の疾患の順で鑑別を進める. それぞれ緊急度の高いものから列挙した ${ }^{2)}($ 表 5$)$.

\section{4. 初期治療}

意識障害の初期治療では, 低血糖に対して迅 速に対応しなければならない.さらに薬物中毒 も否定できない場合には, 昏睡カクテル (coma cocktail）を用いることで診断的治療が可能であ る。昏睡カクテルは，塩酸チアミン（ビタミン B1) $100 \mathrm{mg}$ と $50 \%$ ブドウ糖液 $40 \mathrm{ml}$ と塩酸ナロ キソン $0.4 \mathrm{mg}$ 静注する. 以下に各病態に対す る初期治療を示す.

\section{1) 低血糖}

直ちに $50 \%$ ブドウ糖液 $40 \mathrm{ml}$ 静注する。し かし, 慢性アルコール中毒患者ではブドウ糖投 与によりWernick脳症を引き起こす危険性があ る.これを防ぐため, サイアミン $100 \mathrm{mg}$ をブド ウ糖液投与前または直後に投与する.

\section{2）糖尿病性昏睡}

十分な輸液と電解質の補充およびインスリン の適切な投与を行う. 直ちに生理的食塩水点滴 静注 $(500 \mathrm{ml} / \mathrm{h})$ と速効型インスリンを生理的食 塩水に溶解し 0.1 単位 $/ \mathrm{kg}$ /時間の速度で点滴静注 する。

\section{3）肝性昏睡}

特殊アミノ酸製剂, 高カロリー輸液, ネオマ イシン，ラクッロースを投与する。

\section{4）薬物中毒}

塩酸モルヒネの中毒には，拮抗薬である塩酸 ナロキソンを投与する。 ベンゾジアゼピン系睡 


\section{表 5. 緊急度の違いによる意識障害の鑑別疾患}

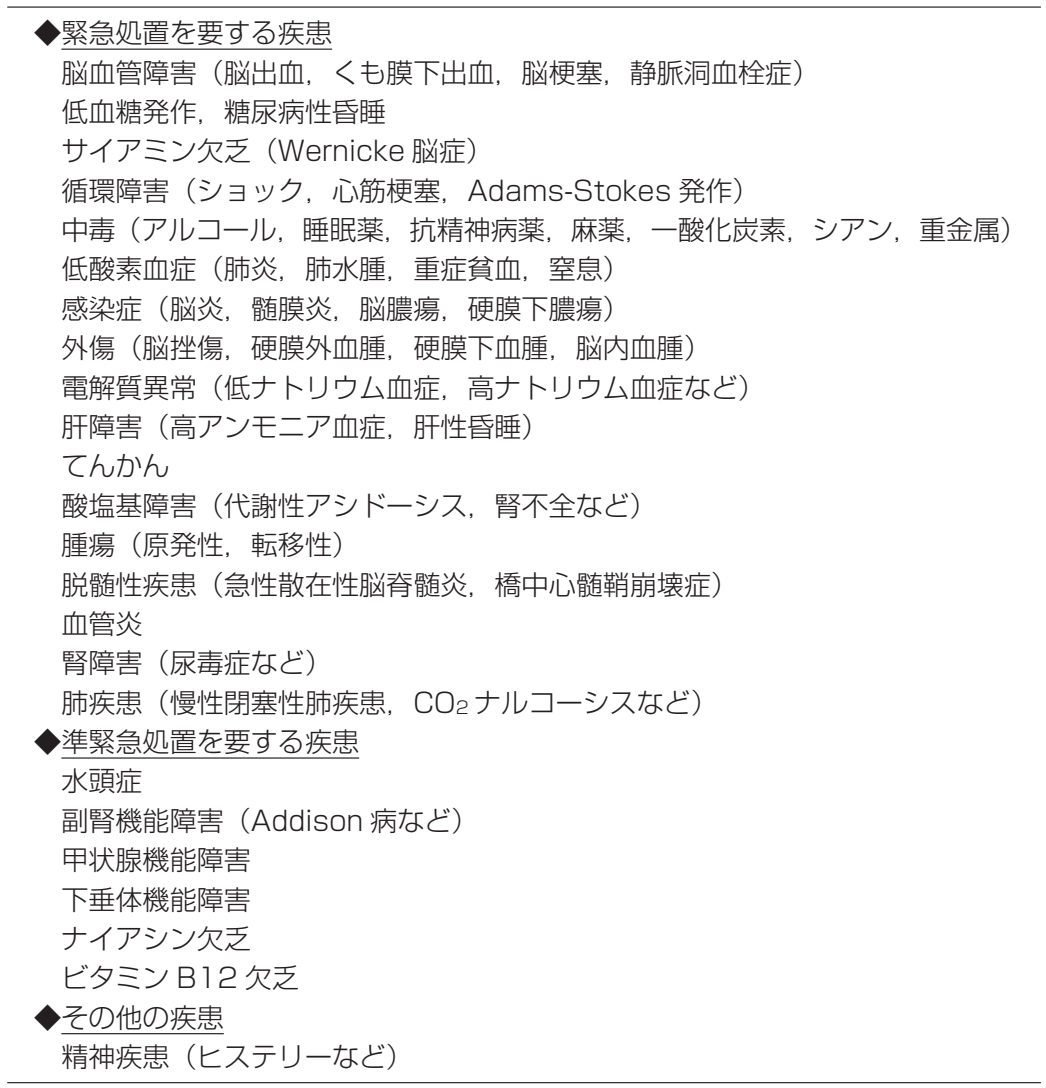

眠・鎮静薬であるジアゼパムの中毒には，特異 的拮抗薬のフルマゼニル (アネキセート $\left.{ }^{\circledR}\right)$ を投 与する. 特にてんかん歴のある患者や複数の睡 眠薬を服用している患者ではけいれんを起こす 危険性が有るので, 病歴の聴取を詳細に行う必 要がある。

\section{5. 専門医への引き継ぎ}

意識障害の背景には重篤な基礎疾患が存在す る可能性があり, 速やかに初期評価を行い, 早 期に気道確保, 静脈路確保, モニ夕を実施した 上で, 頭部単純CT検査を実施する. 特に脳梗塞 において, 3 時間以内にrt-PAによる血栓溶解療 法を行うには, 救急隊からの連絡時または遅く とも来院後局所神経症候を認めた時点で専門医
に連絡する。 また，低血糖，サイアミン欠乏， 薬物中毒では初期治療を開始し直ちに専門医に 連絡する。

\section{1) 脳梗塞 (cerebral infarction)}

脳梗塞の臨床病型は心原性脳塞栓症, アテロー ム血栓性脳梗塞, ラクナ梗塞に分類される. 多 くの場合局所神経症状を認め, 意識障害を伴う 場合は広範囲大脳半球または脳幹部に責任病変 がある. 3 時間以内にrt-PAによる血栓溶解療法 を行う場合には, 救急隊からの連絡時または遅 くとも来院後局所神経症候を認めた時点で専門 医に至急連絡をとる。血栓溶解療法実施には頭 部単純CTでの早期虚血性変化 (early CT sign)の 確認が必要であるため, 同時にCT検查室に連絡 を入れる。 
2) 脳出血 (cerebral hemorrhage)

出血の部位と大きさにより局所神経症状が異 なる. 大脳半球の大きな血腫や脳幹部の血腫で は, 意識障害を伴い予後が悪い. 診断には頭部 単純CTが最も有用である.

3）くも膜下出血 (subarachnoid hemorrhage) 原因は脳動脈瘤の破裂が多い。激しい頭痛や 髄膜刺激症状を認めるが局所神経症状がない場 合や, 突然の高度な意識障害を来す場合がある。 診断には頭部単純CTが最も有用である. 頭部単 純CTで出血が確認できない場合は脳動脈瘤から のminor leakageの可能性があるため, 脳脊髄液 検査を行い血性髄液またはキサントクロミーの 有無をみる.再出血が破裂性脳動脈瘤の $20 \%$ に みられ, 発症後 24 時間以内に最も多いため, 可 及的速やかに外科治療が必要となる.

4) てんかん (epilepsy)

部分発作では意識レベルは保たれることが多 く, 全般化すると意識障害を伴う.頭部単純CT, 頭部単純MRI (magnetic resonance imaging) お よび頭部MRA (magnetic resonance angiography）は頭蓋内の器質性病変の検索に有用である. 脳波検査での発作波の検出は診断に役立つ。ま た，血清CK（creatine kinase）值，動脈血ガス 分析も参考になる.

5）サイアミン欠乏（thiamine deficiency）

サイアミン $\left(\right.$ ビタミン $\left.\mathrm{B}_{1}\right)$ 欠乏により発症する Wernicke脳症は, 意識障害, 眼球運動障害, 運 動失調を 3 徵とする. 原因としては慢性アルコー ル中毒が多いが, 長期低栄養, ビタミン $\mathrm{B}_{1}$ 未補 給の長期持続点滴患者にも起こる. 血中 $B_{1}$ を測 定し診断する．頭部単純MRIは診断に有用であ る. 初期治療開始後, 直ちに専門医へ連絡する.

\section{6）低血糖（hypoglycemia）}

低血糖発作は遷延すると不可逆的な脳障害を 残すことがあるため，迅速な血糖補正は必須で ある. 血算・生化学, 動脈血ガス分析, 心電図, 胸部X線 - 腹部X線を行う. 初期治療開始後, 直 ちに専門医へ連絡する。

\section{7）高血糖緊急症}

糖尿病性ケトアシドーシスと高浸透圧高血糖 症候群との 2 型がある. 血算・生化学, 尿一般, 動脈血ガス分析が診断に有用である。初期治療 開始後, 直ちに専門医へ連絡する。

\section{8）低ナトリウム血症 (hyponatremia)}

低ナトリウム血症に対する急激なナトリウム 補正は, 橋中心髄鞘崩壊症を併発するので要注 意である. 血算・生化学, 動脈血ガス分析, 心 電図, 胸部X線・腹部X線を行う. 補正速度 $1 \mathrm{mEq} /$ $l / \mathrm{hr}$ 超えないナトリウムを点滴に加える.

\section{9）肝性昏睡（hepatic coma）}

劇症肝炎や肝硬変の末期にみられる。傾眠〜 昏迷期には羽ばたき振戦がみられる。黄疸, 肝 機能異常, 肝硬変の存在, 血中アンモニア, 動 脈血ガス分析，脳波が診断に有用である．劇症 肝炎は肝移植の選択もあり, 速やかに専門施設 に送ることが大切である。

10）尿毒症性脳症（uremic encephalopathy）

腎機能障害による尿毒素性毒素の蓄積に電解 質異常などが加わり発症する。痴呆症状にはじ まり，意識障害に進行する。電解質や酸・塩基 平衡の異常を確認するため, 生化学や動脈血ガ ス分析を行う。血液浄化療法が必要となるため 腎臓内科へ連絡する。

\section{1） $\mathrm{CO}_{2}$ ナルコーシス $\left(\mathrm{CO}_{2}\right.$ narcosis $)$}

高炭酸ガス血症による意識障害である。安定 期の $\mathrm{PaCO}_{2}$ から 30 Torr以上, 急性に $\mathrm{PaCO}_{2}$ が上 昇すると発症するとされている。低酸素血症や 呼吸性アシドーシスを伴うことが一般的である. 動脈血ガス分析が診断確定に必須である。予防 には鼻カニューラで低濃度酸素を低流量で投与 する.しかし, $\mathrm{PaCO}_{2} 60$ Torr(パルスオキシメー ター $\left.\mathrm{SpO}_{2} 90 \%\right)$ 以上を維持する必要があり, 非侵襲的陽圧換気療法 (NPPV) も考慮する.

\section{2）薬物中毒}

睡眠薬の大量服用などにより意識障害を来す. 服薬状況などの詳細な問診が重要である。初期 治療開始後, 直ちに専門医へ連絡する。 


\section{おわりに}

本稿では内科救急における，意識障害患者に 対する専門医への引継ぎまでの初期評価および 対応（初期治療）について解説した. 救急診療 において遭遇することが多い意識障害は, 呼吸 障害・循環障害を伴うことも少なくないため, 的確かつ迅速な初期対応, 鑑別診断と早期治療 が求められる.

\section{文献}

1) Posner JB, et al: Plum and Posner's diagnosis of stupor and coma. Fourth edition, Oxford University Press, New York, 2007.

2）水野美邦, 辻 省次：意識障害. 神経内科ハンドブック 鑑別診断と治療. 水野美邦編. 第 3 版, 医学書院, 東京, 2002, 126-145.

3）日本救急医療財団心肺蘇生法委員会監修：救急蘇生法の 指針《2005》医療従事者用. 日本版救急蘇生ガイドライ ン策定小委員会編. 改訂 3 版, へるす出版, 東京, 2007.

4）石見 拓,他：日本救急医学会ICLSコースガイドブック. 平出 敦監修, 日本救急医学会ACLSコース企画運営委 員会ICLS コースガイドブック作成ワーキング編. 改訂第 2 版, 羊土社, 東京, 2007 .

5) Rosenfeld JV, Lennarson PJ : Coma and brain death. Shapira AHV, ed. Neurology and Clinical Neuroscience, Elsevier, Philadelphia, 2007, 97-116. 